DOI 10.37882/2223-2982.2021.05-2.31

\title{
ПОИСК НОВЫХ МОДЕЛЕЙ ИНВЕСТИЦИОННОЙ ПОЛИТИКИ СССР/РОССИИ В ПЕРИОД СМЕНЫ СОЦИАЛЬНО-ЭКОНОМИЧЕСКОЙ ФОРМАЦИИ В КОНЦЕ 1980-Х - НАЧАЛЕ 1990-Х ГГ.
}

\section{SEARCH FOR NEW MODELS \\ OF THE USSR / RUSSIA INVESTMENT POLICY DURING THE PERIOD OF CHANGE IN THE SOCIO-ECONOMIC FORMATION IN THE LATE 1980S - EARLY 1990S.}

\section{A. Sukiasyan}

Summary: The paper deals with the evolution of the investment policy of the USSR / Russia during the period of change in the socio-economic formation in the late 1980s - 1991. The author examines the influence of the changing world economic and geopolitical situation on the implementation of the Soviet state credit policy both in relations with the socialist countries of Eastern Europe and in relation to the capitalist states of the West (USA, Canada, Japan, European countries). The research focuses on the analysis of the institutionalization of financial and economic cooperation between the Soviet Union and Western countries in the 1960-1970s, the formation of the first representative offices of foreign banks in the USSR. The article shows the process of transition of Russian financial institutions to new principles of management in a free market and based on the concept of a liberal economy. The author comes to the conclusion that the investment policy of the transition period of the USSR / post-Soviet Russia has become a significant factor in the activation of transformation processes in the country.

Keywords: the USSR investment policy, Russia, USA, Europe, CMEA, International Bank for Economic Cooperation, "perestroika", liberal economy, Russian reforms of the 1990 s.
A ктуальность темы определяется значимостью инвестиционного сотрудничества для процесса интеграции России в глобальную экономику XXI века и необходимостью изучения исторического опыта международного финансово-экономического взаимодействия. Многие аспекты изучаемой проблемы, в частности, потенциал экономической системы СЭВ, являются предметом дискуссий в современном научном сообществе [3].

Историографическую базу работы составляют научные труды в области истории внешней политики СССР эпохи «перестройки», включая фундаментальные статьи А.С. Барсенкова [1], а также публикации отечественных
Сукиасян Асатур Альбертович

К.э.н., дочент, Башкирский государственный университет saa@s-lab.info

Аннотация: В статье рассматривается эволюция инвестиционной политики СССР/России в период смены социально-экономической формации в конце 1980-х - 1991 гг. Автор исследует влияние меняющейся мировой экономической и геополитической ситуации на реализацию Советской государственной кредитной политики как в отношениях с социалистическими странами Восточной Европы, так и применительно к капиталистическим государствам Запада (США, Канада, Япония, европейские страны). Анализируется процесс институционализации финансово-экономического сотрудничества Советского Союза с западными странами в 1960-1970-е гг., образование в СССР первых представительств иностранных банков. В статье показан процесс перехода российских финансовых институтов на новые принципы хозяйствования в условиях свободного рынка и на основе концепции либеральной экономики. Автор приходит к выводу о том, что инвестиционная политика переходного периода СССР/постсоветской России стала значимым фактором активизации трансформационных процессов в стране.

Ключевые слова: инвестиционная политика СССР, Россия, США, Европа, СЭВ, Международный банк экономического сотрудничества, «перестройка», либеральная экономика, российские реформы 1990-х гг.

и иностранных авторов, посвященные специфике экономических связей СССР со странами Восточной Европы и государствами Третьего мира в контексте начинающихся рыночных реформ [6; 10; 9].

В период трансформационной модернизации переходного периода 1980-начала 1990-х гг. существенно изменяется роль и значение инвестиционного диалога СССР/России как со странами социалистического лагеря, так и с капиталистическим миром. Государственная инвестиционная политика становится в системе идеологии позднего СССР новым направлением сотрудничества С окружающими странами, целью которого является обеспечение финансовыми средствами инфраструктурного 
переоснащения советской/российской экономики.

Научная новизна исследования состоит в том, что автор впервые осуществляет комплексный научно-аналитический подход к теме истории инвестиционного сотрудничества СССР/России в период социально-экономического транзита конца 1980-х - начала 1990-х гг. с учетом геополитических, идеологических, системно-организационных и технологических факторов.

Предметом исследования является исторический опыт инвестиционного взаимодействия СССР/России с иностранными (капиталистическими) финансовыми институтами, практика межбанковского сотрудничества в процессе смены социально-экономической формации на рубеже 1980-1990-х гг. Объектом исследования являются государственные кредитные структуры СССР/России, западные инвестиционные компании, нормативные и программные документы межбанковского взаимодействия.

В середине 1980-х годов, когда в советском обществе начинают впервые в полную силу проявляться новые идеи организации социально-экономического уклада, первоначально в латентной форме, а затем и открыто разворачивается общественная дискуссия о внедрении новых форм хозяйствования, проект привлечения массовых инвестиций в развитие экономики получает популярность в среде советской номенклатуры и в советском обществе в целом [7]. По этой причине начинается эволюция как внешнеполитической доктрины позднего СССР, так и трансформация сферы инвестиционных отношений советского государства с международным финансовым сообществом и бизнесом. Однако на решение стратегической задачи СССР - обеспечение в необходимых размерах капиталовложений в новые индустриальные технологии - у советской социалистической системы уже не было исторического времени: произошедший распад СССР в 1991 году прервал попытки организовать масштабные инвестиции в общесоюзную экономику. В то же время, в контексте политики «перестройки» М.С. Горбачевым в 1985-1990 гг. началась трансформация сферы инвестиционных связей Советского Союза с международным экономическим сообществом (СЭВ и европейские страны Общего рынка, США и др.).

В «доперестроечный» период второй половины 1970-х - начала 1980-х гг. были созданы новые институты международного инвестиционного сотрудничества, в том числе и в рамках стран социалистического блока: так, с 1970 года осуществляется совместная финансовая деятельность государств-членов СЭВ (Совет Экономической взаимопомощи) посредством специально созданного Международного инвестиционного банка (МИБ), который осуществлял как взаимные операционные расчеты стран-учредителей (СССР, Венгрия, Болгария, Куба,
Вьетнам, Польша, Монголия, Чехословакия и Румыния), так и обеспечивал инвестирование совместных инфраструктурных проектов в экономической сфере СЭВ, а также и в других государствах.

В исторический период, приближающийся к этапу смены социально-экономической формации в СССР и странах социалистического блока возникают новые институциональные формы финансового сотрудничества, адаптированные к работе в международном экономическом пространстве и использующие в своей деятельности модернизированные финансовые инструменты: так, Международный банк экономического сотрудничества (МБЭС), а в дальнейшем Международный инвестиционный банк (МИБ) вводит в свою операционную практику расчеты в переводных рублях, что по сути становится уникальным в истории мировых финансов примером использования «коллективной национальной валюты, получившей широкое применение в международной расчетной практике» [5, с.103].

В 1991 году, когда в России произошла радикальная смена социально-экономической формации, финансовые институты советского времени начали адаптироваться к новым условиям деятельности. При этом, несмотря на то, что СЭВ был упразднен, его банковские структуры продолжили работу уже в условиях либеральной экономики и формирующегося финансового рынка, продемонстрировав хороший организационно-административный, финансово-ресурсный и технологический потенциал. Например, МБЭС, пройдя техническое реструктурирование, стал современным технологичным международным банком, осуществляющим операционное обслуживание преимущественно долговременных межгосударственных инвестиционных и торговых проектов стран-бывших членов СЭВ, т.е. реально продолжая работу в своей прежней финансово-экономической нише. Также продолжил свою деятельность и Международный инвестиционный банк, который в 1990-е годы развернул коммерческое кредитование совместных инвестиционных программ, а также проектов развития, осуществляя, в том числе, финансирование инновационных промышленных разработок в странах-учредителях. МИБ так определяет свою задачу: «Содействие сопряженности и интеграции экономик стран-членов Банка в целях поддержания условий сбалансированного и инклюзивного роста, конкурентоспособности национальных экономик с опорой на сложившиеся исторические связи» [4].

Во второй половине 1980-х годов в СССР начинают развиваться процессы политической либерализации, которые ставят на повестку дня вопрос изменения подхода государства и общества к экономическому сотрудничеству с капиталистическими государствами, в том числе изменяется отношение к иностранным инвестициям, ко- 
торые уже рассматриваются как значимый инструмент российской модернизации. Нарастающие в то же время кризисные явления в отечественной экономике создают кумулятивный эффект: западные инвестиции начинают восприниматься как панацея от финансово-экономического кризиса в советской экономике и перспективный механизм развития. В действительности происходила существенная переоценка реальных возможностей иностранных инвестиций для быстрого модернизационного развития экономики России конца 1980-х - начала 1990$\mathrm{x}$ годов.

Выдвинутый М.С. Горбачевым лозунг «нового политического мышления» ввел в общественное сознание новое восприятие Запада и, соответственно, новое отношение к финансово-экономическому сотрудничеству с капиталистическими странами, которое стало восприниматься как конструктивный экономический диалог с зарубежными партнерами. Тема инвестиционного взаимодействия со странами Запада становится одним из приоритетов Международного отдела ЦК КПСС и МИД СССР. Перед ведущими научно-исследовательскими центрами советской теоретической науки - Институтом мировой экономики и международных отношений и Институтом экономики мировой социалистической системы - ставится задача разработки теоретических и практических основ нового экономического курса в отношениях со странами капиталистической системы [1, c.45-46].

В мае 1986 года в МИД СССР на «закрытой» конференции М.С. Горбачев в своем выступлении охарактеризовал социализм как отсталую экономическую систему, не имеющую исторических перспектив развития, и призвал к всемерному расширению политико-дипломатического и инвестиционного сотрудничества с Западным миром [1, с.54]. Таким образом, был создан новый идеологический ориентир финансово-экономического взаимодействия с иностранными (капиталистическими) государствами, в том числе и в банковской сфере [9].

Одновременно с утверждением концепции либеральной экономики в трансформирующемся российском социуме происходит распад системы прежних финансово-экономических связей социалистического содружества СССР и стран Центральной и Восточной Европы. В первую очередь это было обусловлено истощением у Советского Союза финансовых ресурсов для инвестирования в хозяйственный комплекс СЭВ; в то же время руководство ГДР, Венгрии, Чехословакии и др. проявляли настороженное отношение к идеям и практике советской «перестройки». Эти настроения активно поддерживались США и ведущими государствами Западной Европы [1, с.37-38].

\section{В 1989 году Правительство СССР заявило о переходе}

в системе взаимных расчетов СЭВ на рыночный принцип: инвестиционные операции отныне совершались по мировым ценам и за конвертируемую валюту. По сути, это означало завершение эпохи финансового патернализма со стороны СССР и переход на взаимодействие в соответствии с принципами финансово-экономического прагматизма.

Также на рубеже 1980-х - 1990x гг. СССР/Россия пересматривает свои инвестиционные отношения со странами третьего мира в соответствии с изменившейся геополитической ситуацией[8]. При этом поиск путей модернизации хозяйственных отношений в рамках социалистического блока фактически был завершен, и инвестиционные взаимоотношения в лагере бывших идеологических союзников уже начинают выстраиваться в соответствии с рыночными принципами.

В конце 1980-х гг. деловые круги западных стран, прежде всего США и Европы, проявляют стремление к расширению финансово-экономического сотрудничества с СССР и странами социалистической Восточной Европы. В 1989 году был подписан ряд концептуальных Соглашений между СССР и западными странами о поощрении и взаимной защите капиталовложений: с Бельгией, Великобританией, Францией, ФРГ, Канадой, Нидерландами, Италией. На протяжении 1990 года аналогичные Соглашения были оформлены с Испанией, Австрией, Южной Кореей, Швейцарией.

В 1991 году после образования Российской Федерации в рамках государственной внешнеэкономической политики утверждается курс на максимальное развитие финансово-экономического сотрудничества со странами Запада (США, Евросоюз, Япония и др.), интеграцию российских банковских институтов в мировое финансовое пространство. При этом приток иностранных инвестиций в новую российскую экономику воспринимается как значимый фактор ее модернизации, перспективное направление экономического сотрудничества. Начинается новый этап финансово-экономического взаимодействия России со странами Западного сообщества.

Таким образом, важнейшими компонентами трансформации инвестиционной политики СССР/России В эпоху «перестройки» во внешнем финансовом пространстве стали следующие обстоятельства:

- первые институты инвестиционного сотрудничества СССР со странами Запада возникают уже в 1970 - начале 1980-х годов; но они еще не имеют массового характера, а их деятельность ограничена решением конкретных экономических задач;

- советская идеология «развитого социализма» отдавала приоритет финансовому взаимодействию СССР со странами социалистического блока (ГДР, Венгрия, Польша и др.), при этом Советский Союз 
руководствовался принципами государственного финансового патернализма, в ущерб экономической целесообразности;

- появление в советской экономике западных инвестиционных средств в 1980-е гг., с одной стороны, способствовало притоку дополнительных финансовых ресурсов в социалистическое народное хозяйство, но с другой - показывая эффективность западных рыночных механизмов, вело к размыванию идеологических принципов социализма в экономике и к реинтеграции советской финансово-экономической системы в мировое капиталистическое хозяйство;

- в период начала 1990-х гг. происходит формирование в России институциональной основы инвестиционного сотрудничества, основанного на принципах свободного рынка и финансовом прагматизме;

- в начале 1990-х годов в России происходит определенная переоценка роли и возможностей зарубежных инвестиций для модернизации отечественной экономики, увеличение прямых иностранных инвестиций (ПИИ) начинает рассматриваться в качестве панацеи для преодоления кризиса и перехода к экономическому росту;

- утверждение в новой России с 1991 года идей либеральной экономики и свободного рынка способствовало притоку западного инвестиционного капитала в модернизирующуюся социально-экономическую систему.

\section{ЛИТЕРАТУРА}

1. Барабанов М.В. Европейское сообщество и социалистические страны Восточной Европы в годы «разрядки»; его глубинные интересы в развертывании экономического сотрудничества // Вестник МГОУ. Серия: История и политические науки. 2018. № 1. С. 37-44.

2. Барсенков А.С. «Новое мышление» во внешней политике СССР (1985-1991) // Вестник Московского университета. Серия: Международные отношения и мировая политика. 2012. №1. С.41-72.

3. Круглый стол «Экономическое сотрудничество стран (ЭВ: мотивы, ресурсы и вызовы Холодной войны». Челябинск, 18 января 2020 г. [Электронный ресурс] // Сайт НИУ ВШЭ в Санкт-Петербурге. URL: https://spb.hse.ru/humart/chr/eth/news/332989327.html (Дата обращения: 12.03.2021)

4. Международный инвестиционный банк. Ключевые факты [Электронный ресурс] // Сайт МИБ. URL https://iib.int/files/klyuchevye_fakty.pdf (Дата обращения: 15.03.2021).

5. Никитина М.Г., Мираньков Д.Б. Банковские институты СЭВ в условиях современности // Ученые записки Таврического национального университета имени В.И. Вернадского. Серия «Экономика и управление». Том 26 (65). 2013 г. № 1. С.101-108.

6. Полынов М.Ф.. «Доктрина Горбачева» и уход СССР из Восточной Европы // Новейшая история России. 2011. № 2 (2). С. 107-121.

7. Bond, Andrew R. "Spatial Dimensions of Gorbachev's Economic Strategy," Soviet Geography,Vol. 28, No. 7 (September 1987), pp. $490-523$.

8. Fukuyama, Francis. The Tenth Period of Soviet Third World Policy Santa Monica, Calif.: RAND Corporation, 1987. 29 pp.

9. Gutman P. "The opening of the USSR to foreign capital”, The Soviet Union and Eastern Europe in the global economy, ed. by M Lavigne, Cambridge: Cambridge University Press, 1992, pp.133-144.

10. Kanet, Roger E. The Soviet Union, Eastern Europe and the Third World. Cambridge University Press, 1987. 233 pp.

(с) Сукиасян Асатур Альбертович (saa@s-lab.info). 